6. 前記諸アミノ酸の試醀酒の夏季町藏に就ては冷藏庫內に之を眝藏せしを以て何れも火 落せす從つて其差異は認め難し。

之を要するにチロシン及びフェニールアラニンの如きつェノール基を有するアミノ酸は 酒質を惡化する傾向颖著をるが故に原料米を選擇するに當り斯の如き種類のアミノ酸の含 量少き蛋白質を含むものを可とすべし。之に反してアラニンの如き低級なる分子のアミノ 酸を多量に含有する蛋白質を含屯原料米は酒造用として優良なりと謂はざるべからず。特 に酒母に於てはアミノ酸の分解過激なるが故に酒母用米の選擇に當りては更に以上の事賽 连重視するの要あり之認む。

\title{
醬油の徽止劑に就て
}

(特に「ビオデパール」に就て)

（飲食物防腐劑の研究）其四八一

\section{醫學博:太 太田賢一郎}

\section{序說}

本誌三月號 (1)に於て余が行ひたる千百數種の倠機合成色素つ消毒試驗站に毒力测定の ·結果 Diphenylmethane, Triphenylmethane, Aniline Black 等の色素の誘導體及中閒成績 體に就て㸴究の步武を進めつつあるを述べたり。而してその化合體百五十種中稍々優秀な

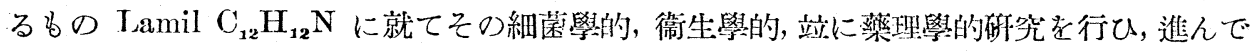

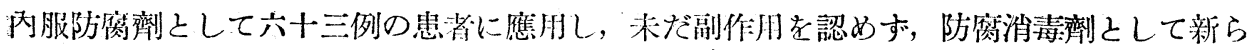
しく應用し得ることを明にし，詳細なる㸴究成績を報告（40）せり。

次に余江本物質を經口的に投與して後人體內に於て如何なる變化を受け，如何にして排 泄せらるるかの問題を探究し，本物質が體內に於て酸化せられ，「エーテル」硫酸と俱に Biodipal「ビオヂパール」として尿中に排泪せらるるてと（41）を確認せり。乙の酸化成 績體は恰も樟腦と Allo-p-Oxocampher（明村及朝比奈博士）との藥理作用に差違のあるが

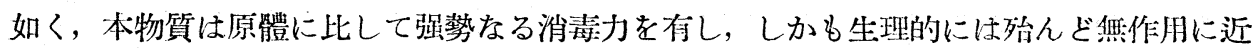
き物質にして，余が今日迄取り扱ひたる千三百有餘種の化合物中最も優秀なる衛生的醬油 防窝劑なるてとを確認せり。即ち「ビオヂパール」は牦色無臭の化學的に安定なる化合物 にして，毒力は「サリチル」酸の四分の一即ち毒性殆んど牦く，薬理學的，內科學的站に 病理解剖學的䂰究により然毒なるてとを證明し，工業的に使用して最も優秀なるてとを認 めたり。その防腐力は三萬乃至六萬倍有效にして，その效力は永久不變なるてとも證し得 たり。次にその研究要旨を述べんとす。 


\section{第一章 各種誘導體の合成}

A. 108. O-Aminodiphenylamin

Kehrmann u. Havas 兩氏 (2) の記載に從ひ，o-Nitrodiphenylamin より製造す。郎ち この物質の川溫酒精溶液に Zinnchlarur を發煙監酸に溶解せるものを混和し，乙の混合液 を水浴上にて充分に熱し，「ニト口」化合物の發生せざるに至らば，酒精分のみを加溫分溜 し，てれに倍量の水を扠振湯しつつ冷却す。乙の際成生する結晶を集め輕く水洗し，再

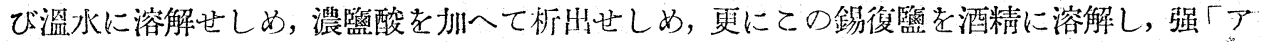
ンモニア」水を加へて「アルカリ」性とすれば，本䧗基は始め乳白色に溷濁して析出すれ ぞも，間も無く結晶す。ての物質は攝氏八十度內外にて㵋解す。

A. 109. p-A minodiphenylamin

Hochst Farb. G.P. 134559. Dipheynl Black I Base (MIB) (D. 14) を州ふ。

A. 110. p-Aminodiphenylamin-o-Sulfosäure

P. Fischer 氏 (3) に從ひ o-Anilido-m-nitrobenzolsulfonsäures Baryum t Eisenoxydulhydrat にて還元し, その「バリウム」鹽を硫酸にて分解して得可し。本物質は空氣に䚪 れて潮時晤黑色に變ず。

A. 111. Acetyldiphenylamin

Claus 氏 (4) (5) に從ひ Diphenylamin 之醋酸無水物之を等分子量の割合に混和し，「キ シロール」內にて加熱し「アセチリーレン」「ェーテル」より再結晶す。

A. 112. p-Aminoazotoluol

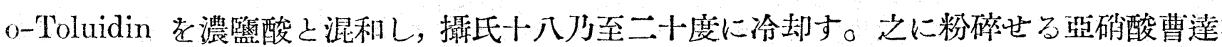
を徐ハに玔一攪排す。溫度は搨氏三十三度以上となさず。約三十分間して後滤過し，少量 の水にて洗ひ乾燥器內に保存す。その儘二日以上を經過すれば少量同時に生成されし Diazoamidotoluol \&完全に Aminoazo 化合體となる。

A .113. o-Aminoazotoluol

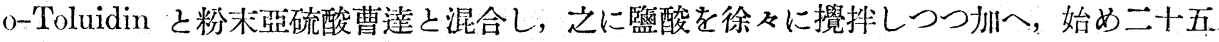
度內外, 後に三十度乃至三十五度に加溫す。次で犬十乃至七十度に加溫し溶解せしめ後監 酸を加へ良く混和し，更に水を加一析出せし結晶を監酸水にて浘沙す。本物質は水に難溶 性にして熔點は百度なり。

A. 114. p-Aminoazobenzol

Stadel u. Bauer 网氏 (6) に從ひ, 少づ Diazoaminobenzol を三倍重量の「アンリン」に 溶解し，十分の一重量の鹽酸「アニリン」常溫にて加一混和し，之を攝氏四十度に一時間 放置し, 後水浴より取り出し室溫に一畫夜放置す。次で之に濃監酸の一定量を(「アニリン」 


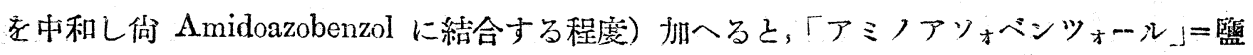

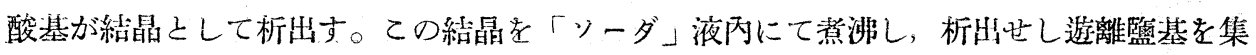
あ「「ベンツォール」より再結晶す。黃裀色の結晶にして熔融點は一二六展內外なり。

A. 115. Acridin

本品は E. Merck 社製の純品を用ひたり。

A. 116. p-Aminodipheryl

Schlenk u. Weickel 网氏 (7) に從ひ Zinnchlarur の濃壁酸溶液內一 p-Nitrodiphenyl の酒精溶液を徐々に加一, 整時放置し, 後三十分間程水浴上にて加溫し後冷却すれば結晶を 析出す。ての結晶を「アルカリ」液內にて遊離監基とし，てれを「ェーテル」より再結晶 す。光辉ある結晶にして五十三度にて熔融す。

A. 117. o-Aminodiphenyl

Dimroth 氏 (8) に從ひ, 先づ警酸酸性一Zinnchlorur「エーテル」溶液內に o-Nitrodi-

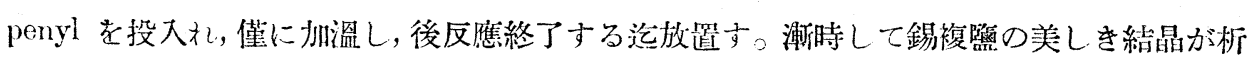
州す。ての結晶を集め,「アルカリ」性となし「「ーテル」に採り，石油「ェーテル」より 再結晶す。熔點は四十八度にして鏳狀の結晶なり。

C. 106. p-Chloracetanilid

E. Merk 社製品を用ふ。

C. 107. p-Chloranilin

「アンリンはより製造す。

C. 108. Cystopurin

ウロトロピン」の誘導體にして $\mathrm{C}_{6} \mathrm{H}_{12} \mathrm{~N}_{4} \cdot 2 \mathrm{CH}_{3}-\mathrm{COONa}-6 \mathrm{H}_{2} \mathrm{O}$ の分子式を有す。

D. 108. Diphenyl

E. Fischer (9) に從つて製す。印ち燃燒爐の代りに朝此奈式簡單燃燒器を使用し,「べ ンツォール」フ約七時間皮熱セリ。コノげンツォール、溶液を油糟にて加熱し, 約二百二

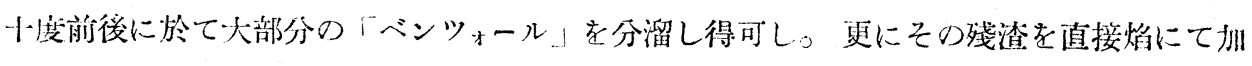
熱し，二百五十度乃至一百七十五度に於ては淡黃色の結晶性物質を得。乙の物質を酒精よ り再結晶して本品老得可し。揢融點は七○・五度。板狀の結晶にして、「ベンツォール」及熱 酒精には易溶性なれども，水には㱠んど溶解せす。

D. 109. Diphenylamin

メルク社製品老且ふ。

D. 110. p, p'-Dinitrodiphenylamin

Barbier 及 Sisly 爾氏(10)の方法に從つて先づ合成す。即ち乳鈛內にて粉碎せる Chlor* hydrate de paraminaozobenzene t亞硫酸瓦斯䘮飽和せしめたる冷水中に浮遊せしめ，てれ。 


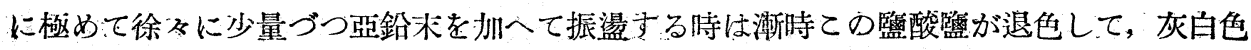
の沈澱となりて器底に沈む。次に硫酸を招へ办熱し，沰膫するを待ちて冷却し翌日迄放置 す。然る時は本品の硫酸䉚の結晶を得ると云ふ。郎ち兩氏の報文の一部を抄錄せば

"Lorsque la masse est entiérement décolorée on la verse dans 'me capsule contemant $50 \mathrm{gr}$. d'acide sulfrique dissous dans $50 \mathrm{gr}$. d'eau, on fait boilli et on abondonne jusqu'ou lendemain. On requeille alors un abondant dépot cristallisé de couleur grise que l'on essore et qu'on lave a plusieurs reprises avec de petites quanqités d'eau.” の如し。

右の如く記載しあれども，硫酸添加後紫色を呈し，その沈澱中より本品を抽出するてを

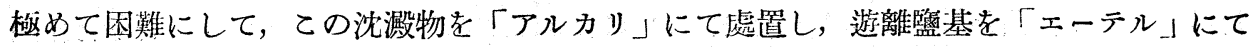
抽出するも僅少量を得るに過ざず。次に Nietzki 氏 (11) に從ひ salzsaures p-Phenylendiamin そ salzaures Anilin 重「クロム」酸加里をを化合せしめて青色酸化物 Indamin を得。ての物質を亞鉛末と共て㱺酸中にて加溫還元して得る方法なり。本法によるも收量 少し。

余は先づ p-Bromanilin 及び p-Diaminobenzol を造り, 兩者を一分子當量宛の割合に 混合し，觸媒として○・一正位の銅粉を玑一，泊浴上にて二百二十度位五時間保ち，後「ェ ーテル」に抽州し再結晶して得たり。收量は等しく僅少なれども精製に便なり。
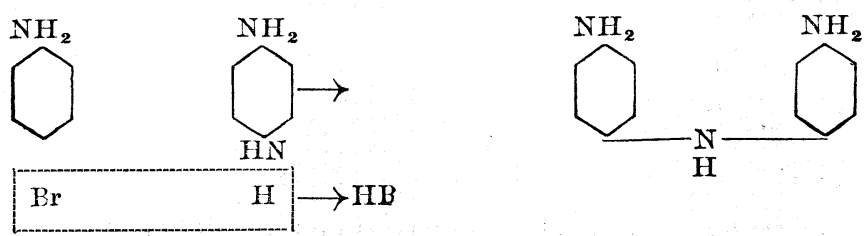

D. 111. p, $\mathrm{r}^{\prime}$-Diaminoditolylamin

Barbier et Sisley 兩氏 (10) が p, $\mathrm{p}^{\prime}$-Diamino diphenylamin を造ると同樣の遇式に從 ひ, Aminoazoique dérivé de l'-o-toluidine の㯺酸監索還元し p, p'-Diamincdicrésylamine を得可し。ての方法は收量更に少し。

余は o-Toluidin とo-Toluidin-chlorhydrat とを當分子量混合し油浴內にて攝氏二百度 にて三時間加熱し反應の終了するを經驗せり。

D. 112. Diphenylaminsulfonsäuee (N-Phenylsulfanilsäure (?) 4 (?)-Anilino-benzolsulfonsäure

Genehm 氏 (12) (13) 等の記載に從ひ，先づ發煙硫酸（ $\mathrm{SO}_{3}$-含量二○\%以上）を五度に 冷却し，てれに Acetyldiphenylamin を徐ふに加へ, 後四十五展にて二時間加溫す。次でて れに水を老玑一，更に二時間煮沸す。本物質は水及酒精に溶解し易し。

D. 113. Diphenylhydroxylamin 
、本物質は極めて分解し易く，製造せし翌日速に科量し檢索に使肺せり。.先づ- E. Fischè D Anleitung に從ひ Brombenzōl t造り，Beilstein (14) k從ひ Nitrobenzol \&り Nitrosobenzol を造る。次に Wieland u. Ruseeu (15) に從ひ本物質を合成す。郎ち「マグ ネシウム」と「ブロームベンツォール」とを混じ，てれに乾燥せる「エーテル」を加へ，充 分に冷却す。乙の中に完全に乾燥せる「ニトロベンツォール」の「エーデル」能和溶液を滴 下寸。。かくして冷所に一畫夜密栓放置し，翌日褐黃色の「エーテル」液を氷片中に注ぎ达 み上層の「エーテル」部分を探り，氷中にて冷却しつ小監化石灰を版て水分を脫却儿，然 る後水浴上にて攝氏二十度內外にて「オイルポンプ」の力を藉りて「ェーテル」を分溜發 散せしむ。この際「コルベン」栓の毛細硝子管よりは水素瓦斯を揆る可し。ての殘渣老石 油「エーテル」にて洗淮し不純物を除去し,更に石油「エーテル」より再結晶す。本品は撮 氏六十度に於て直ちに分解す。

D. 114. Diphenylnitrosoamin (N-Nitrosodiphenylamin)

H. Wieland u. E. Schamberg 兩氏(16)に從つて製造す。郎ち九六\% 酒精に Diphnylamin を溶解し，攝氏五度內外に冷却し，てれに冷却したる濃鹽酸を加へ，更に亞硝酸曹達 液を混入し，暫時の後濾過し，ての粗製品を「リグロイン」より再結晶す。六十六度にて熔 融する板狀結晶なり。水に溶解し難し。

D. 115. Diphenylmethan (Benzylbenzol)

Friedel u. Balsohn 兩氏 (17) に從ひて造る。郎ち逆流冷却器と分液漏斗とに結合する 枝付「コルペン」內に Benzylchlarid と「ベンツォール」とを入れ，更に鹽化「アルミニ ウム」を加へ時々振蕰しつ〉數時間作用せしめて造る。無色の結晶にして二十六度內外に 於て熔融す。水に難溶性をり。又 A. Klages u. Allendorff 兩氏(18)に從ひ, Benzophenon を無水酒精に溶し，之に「金屬ナトリウム」の細片を投入し，水浴上にて沸騰せしめ還元し て得らる。收量約八○\%。

D. 116. Dioxydiphenylmethandikarbonsäure

Geigy u. Comp. 會社の特許 (I.R.-P. 49970) に從ふ。即ち「サリチル」酸と」フォル マリン」と監酸とを蒸發皿に採り水浴上にて玑溫しつ」攪挥すると遂には全部が白色の泥

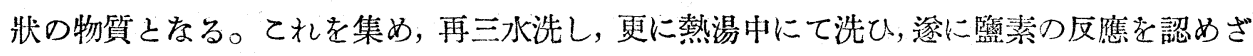
るに至りて止む。酒精及び水より再結晶す。熔點は二百八十五度前後。水に難溶性なれど も, その「アルカリ」監は溶解し易し。

D. 117. p-Dimethylamidobenzophenon

(p-Benzoyldimethylanilin)

Döbner 氏 (19) の記載に從ふ。郎ち Malachite Green を濃覧酸內に溶解し，數時間百 入十度に熱して分解せしむれば Dimethylanilin と Benzoyldimethylanilin とを化咸す。 
後者を分解するには，ての液を多量の水に大る〉と無色の結晶㥞物質として析出す。ての 析出物と「エーデルに採り，酒精より再結晶す。攝氏九十度にて熔融する無色の結晶な D。

D. 118. o-Dinitro-p-Kresol

メルク社製品を用ふ。

D. 119. $\mathrm{p}-\mathrm{p}^{\prime}$-dioxydiphenyl ( $\mathrm{p}, \mathrm{p}$-Diphenol)

Hirsch 氏 (20) に從ひ, Benzidin を稀監酸に溶解し, 更に硫酸を加一, 次で亞硝酸曹達 液を徐々に加一酸化せる後ての液に水蒸氣を通じ沸騳せしむる時は灰白色の沈澱として生 成さる。乙の物質を集め水洗し，熱湯より再結晶する時は白色の輕き結晶となる。熔融點 は二百七十度前後なり。水に溶解し難し。

D. 120. Diazoaminobenzol

Willstätter 氏（21）に從ひ，Anilinchlorhydrat を水に溶かし，同量の水片を入れ零度 に冷却す。渊黄褐色牛透明の液に亞硝酸曹達溶液の泠却せるものを徐々に加ふ。約三十分 の後に黃色の沈澱を多量に析出す。てれを集め乾燥し、「ヘンツォール」より再結晶す。融 點百度。

H. 102. Hexanitrodiphenylamin, p-Dipikrylamin

Vanino（22）の記載に從つて製造す。郎ち Diphenylamin を比重一・八四の硫酸に溶解 し冷却す。乙の液を比重一・五の極めて良く冷却せる确酸山一徐々に混和し, 溫度が十度を 越えざる樣に調蓈す。次でての混合物を水浴上にて徐々に加溫し，最早 $\mathrm{NO}_{2}$ 瓦斯の發生 せざるに至りて止む。ての液を充分に冷却せる後水中に傾潟すれば淡黃色の結晶を生す。 ての物質を集め「メツッェ」上にて完全に水洗してて酸分徐去し,次で酒精より再結晶して 純品となす。淡黃色の結晶にして水に難溶性，二百三十八度にて熔融す。

H. 103. Hexamecol $\mathrm{C}_{6} \mathrm{H}_{12} \mathrm{~N}_{4} \cdot 3 \mathrm{C}_{6} \mathrm{H}_{4}(\mathrm{OH})\left(\mathrm{OCH}_{3}\right)$

本物質は「グアヤコール」と「ウロトロピン」との縮合物にして，陸軍被服本嫾防徽硼 究室鳲農學士上り分讓せらる。

H. 104. Hetoralin $\mathrm{C}_{6} \mathrm{H}_{32} \mathrm{~N}_{4} \cdot \mathrm{C}_{6} \mathrm{H}_{4}(\mathrm{OH})_{2}$

「ウロトロピン」と石炭酸との縮合體にして，堀氏より分讓せらる。Resorcin-Urotropin なり。

I. 102. Imidodiphenyl (Carbazol)

第一に Schoppf (23) 氏に從ひ Phenylazimidobenzol を造る。郎ち o-Amidodiphenyla-

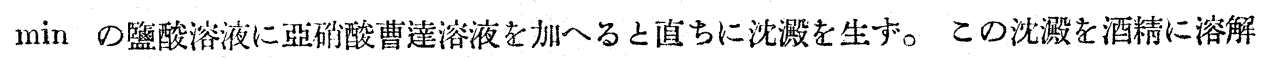
し, 水を加へ數時闒放置する時は淡赤色の絬晶を生ず。その熔融點は九十度前後なり。か くして得たる Phenylazimidobenzol を「コルベン」に移し Gräbe u. Ullmann 兩氏(24) 
に從ひ，三百六十度內外に加熱する時は多量の管素瓦斯を發生しつ১, Karbazol が溜出せ らる可し。この物質を酒精に溶解し, 少量の茢性加里を加へ, 更に水を添加して純品を析出 せしむ。無色板狀結晶にして二百三十八度にて揢融し水に難溶性なり。

K. 101. Kresoform.

ソンルムアルデヒド」と「クレオソート」との縮合體なり。崛學士上り分讓さる。

M. 102. Methyldiphenylamin

Ullmann 氏 (25) に從ひ Diphenylamin 老 Methylieren して造る。郎 Diphenylamin と Dimethylsulfat（兩者共に坊開販賣せらる〉品）上老混和して水浴上にて州溫す。次で

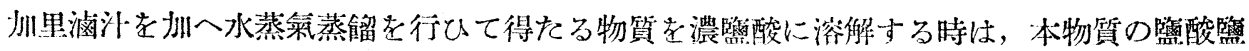
が結晶析出す可し。ての物質考び「アルカリ性となして水蒸氣蒸餾を行へば純品を分 離し得可し。娜騰點三百九十一度の惡臭ある液體をり。

M. 103. Methyldiphenylaminsulfonsäure

(4) (?) Methylaminobenzolsulfonsäuse - (1)

Beilstein (26) の記載に從ふ。Methyldiphenylamin t濃硫酸に溶解し攝氏百六十度に 十時間加熱して得可し。水及酒精に熔解し易し。

M. 104. Malachite Green Lenkobase

Gattermann 氏 (27) 記载に從ふ。Dimethlamilin と Benzaldehyd と血化亞鉛とを混 和熔合せしめ, 後冷却せしめ, 粉末となし數時間水溶上に扠溫す。次に熱水と共に「コルベ ン」內に流し达み，てれに水蒸氣を通じ氣發物を驅逐す。殘留せる館樣物質を尃三加溫水 洗し後酒精に溶解し冷所に一夜放埴す。涠色の結晶上して析出し收量多し。

N. 106. o-Nitrodiphenylamin

先づ Ullmann 氏 (28) に從つて o-Nitroanilin より o-Nitrochlorbenzol を造る。次で ての物質より Kehrmann u. Hava's 网氏 (29) に從つて o-Nitrodiphenylamin を造る。 郎ち o-Nitrochlorbenzol と「アニリン!之乾燥し粉㶬となせる醋酸曹達とを混じ「コルベ ン、に收め, 油浴內にて十二時間州熱す。その湿度は正碓に二百十五度內外とせり。次で

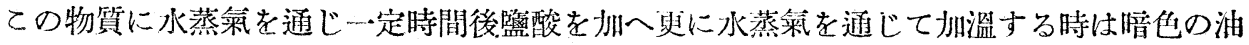
狀物として o-Nitrodiphenylamin 起析活す。この物質を酒精より再結晶すれてば, 溶融點七 け五度の赤黃色板狀結晶として純品学得らる。

N. 107. Nitrotoluol

市內肘賣品を朋ふ。

N. 108. p-Nitrodiphenyl

Keller 比 (30) 及 Lüdens 氏 (31) に從ひて製す。先づ Diphenyl 老熱き水醋酸に溶 加し，之を六十度に冷却し．赤色發煙硝酸之水醋酸を加一暫時して二十五度內外に冷却し 
一鳌夜放㗨す。析出せる結晶を集め，酒精より再結晶す。黃色針狀結晶にして熔融點は一 一四度なり。

N. 109. o-Nitrodiphenyl

p-Nitrodiphenyl の製造に當つてその結晶を滤別せし後水を加一, 殘りの該物質を析出せ しめし後「エーテル」に移行する油狀物質を得。減壓蒸餾にて精製す。

O. 108. 8-Oxychinolin

本品はメルク社製品を用ふ。

P. 105. p-Phenylendiamin

メルク社製品学用ふ。

T. 103. Thiodiphenylamin (Phenthiazin)

Ackermann 氏の D.R.-P. Nr. 222879 に從ひ Diphenylamin と粉末硫黃と乾燥粉碎せ る篮化「アルミニウム」を混和し, 徐々に加熱し, 百四十度乃至百五十度となす。硫化水素 の發生変ふるに及び熱度を百三十五度內外とし, 更に反應の終局に近かば, 再び百五十度內 外に加熱し後冷却す。かくして得たる灰白色の塊を粉碎し水洗し酒精より再結晶せしむ。 熔融點は百八十度內外にして異色の結晶なり。水に溶解せす。

T. 104. Triphenylamin

J. Goldberg u. M. Nimerovsky 兩氏 (32) に從ひ 'Diphenylamin を Phenylieren し て製す。郎ち Diphenylamin 沃度「ベンツォール」炭酸加里及銅片とを混合し，てれに「二 トロベンツォール」を加へて十二時間加熱す。乙の溶液は黃色調を增し漸次褐色暗褐色と なり沃度加里を析出す。次にての液を水蒸氣蒸餾にかけ、本物質を分離す。てれを酒精よ り再結晶する時は百二十二度にて熔融す。「ベンツォール」には易溶性なれど，水には殆ん ど溶解せず。

T. 105. Triphenylmethan

Tschitschibabin 氏 (33) に從ひ, Triphenylcarbinol より製造す。郎ちての物質を少量 の水醋酸に溶解し，之に沃化水素水醋液を加一，沸騰する迄加熱する後速に冷却し水中に 流し达む。これに Na. bisulfit を加ふ。次で析出せる物質を「エーテル」に採る。ての 「ェーテル」を水及「アルカリ」溶液で洗ひ，更に水にて洗滌す。ての「ェーテル」を蒸發 し殘涬を酒精から再結晶する。熔融點は九十二度內外。水に難溶性, 酒清に溶解す。

T. 106. p-Toluidinoxatla

p-Toluidin 監酸水に溶解し，之に葆酸を加へ冷所に放置すれば析出す。

T. 107. p-Toluolsulfodichloramid

メルク社製品を用ふ。

T. 108. p-'Toluidin 
普通の製品を求め, 少量の「ベンツォール」に溶解し, 之に石油「ェーテル」を加入析出 結晶せしめ「ヌッッェ」上に集め, 自然に乾燥せしむ。

T. 109. o-Toluidin

晋通の o-Toluidinを監酸水に溶解し，之に葆酸を加へ五乃至十度に一書夜放置す。こて に析出する p-Toluidinoxalat を滤別し，その母液を「アルカリ」性とし，水蒸菊蒸餾を行 ふ時は殆んど無色の o-Toluidin を得。その內に萠性井里を加へ脫水して使用す。

U. 101. Urotropinchlormethylaether $\mathrm{C}_{6} \mathrm{H}_{12} \mathrm{~N} \cdot \mathrm{ClCH}_{2} \mathrm{COCH}_{3}$.

堀學士より分讓せられしもの。

Y. 101. Yatren (Behring)

8-Oxychinolin の沃度置換體にして 7-jod-8-oxychinolin-sulfonsäure-Ioretin 8: Natrium bicarbonicum 2 の割合の混合物なり。毒性弱きも, 消毒力殆んどなきが如し。No. 105 と稱する商品を贌大せり。

\section{酒宴の席上皇潳を拜す}

初め雄略天皇市邊押磐皇子を害す皇子に二子あり。億計及で弘計と云ふ二 皇子難を避けて播磨の縮見の屯倉首の家僮となる，偶々播磨の國司小楯貢を 徵して首の家に宿す。弘計實を告げて屈を件べんとす。隐計固く不可とす既 にして酒酣なり。首二子に命じ歌はしむ。弘計意を決して歌によりて其の皇 統なることを表はす。小楯警ろき拜して棠を築き之れに招し馳せて之れを當

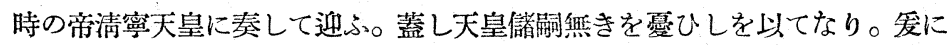
於て億計王を立てて皇太子とし弘計王を以て皇子とす。其の後清寧天皇崩じ て弘計王先づ位に郎き給ひ後億計王帝位に郎き給ふえれ顯宗。仁賢天皇なり。 酒德 一班 